SHS Web of Conferences 10, 00051 (2014)

DOI: $10.1051 /$ shsconf $/ 20141000051$

C Owned by the authors, published by EDP Sciences, 2014

\title{
Improvement of self-organization, relations and learning motivation of different age students by integrative teaching methodology
}

\author{
D. Voita ${ }^{1,2}$, E. Valevica ${ }^{1,2}$, J. Porozovs $^{1}$, and A. Kaulina ${ }^{1}$ \\ ${ }^{1}$ Riga Teacher Training and Educational Management Academy, Latvia \\ ${ }^{2}$ Research Institute of Cardiology of the University of Latvia, Latvia
}

\begin{abstract}
An integrative teaching methodology was developed by qualified specialists and implemented in 17 Latvian schools during one study year. Students who participated in the learning of integrative teaching methodology were divided into 3 age groups: $3-4 ; 5-7$ and 8-12 grade students. Students and teachers who participated in the teaching of integrative teaching methodology were questionnaire before and after using of this methodology. The questionnaires about self-organization problems, relations between students and behaviour of students were filled by teachers but the questionnaire about the learning motivation of students was filled by students themselves. The results of questionnaire showed that problems of self-organization, motivation, hyperactivity, attention deficiency, social anxiety, communication and depressive symptomatic of students who were taught according to the integrative teaching methodology of general schools have reduced in all age groups but in 5-7 and 8-12 grade groups of student's aggressive behaviour reduced as well. Self-organization and behaviour problems of students from special schools after realizing integrative teaching methodology have less reduced in comparison with students of general education schools. In general education schools as well as in special schools external learning motivation and internal learning motivation of all age students increased but am motivation or lack of motivation to learn decreased.
\end{abstract}

\section{Introduction}

Teaching methodology in the pedagogical and psychological literature could be defined in various ways. One of the definitions is that teaching methodology is a set of techniques of mutual cooperation between teachers and students which is necessary in the framework of a certain didactic principle or pedagogical approach and designed to provide training, education and development tasks of teaching and learning objectives and reaching of educational goals (Pedagoìjas terminu skaidrojošā vārdnīca, 2000). Teaching methods are mainly determined by educational aims, objectives and content etc., as well as teacher's understanding about efficiency of one or another method (Mikselsone, 2002). Integrative teaching methodology is based on connecting and summarizing of knowledge from different subjects in order to create better understanding of different disciplines and improvement of competences in general. One of the goals of integrative teaching is to link school and extracurricular cultural life events (Šmite, 2005). Contemporary pedagogy demands the use of integrative teaching methodology to achieve the

This is an Open Access article distributed under the terms of the Creative Commons Attribution License 4.0, which permits unrestricted use, distribution, and reproduction in any medium, provided the original work is properly cited. 


\section{SHS Web of Conferences}

best results. Integrated teaching promotes the formation of a structured view about the world, secures the formation of a humane and open-minded personality and provides a link between studies in the classroom and the real life (Anspoka, 1999).

Learning, emotional and behavioural problems are the most typical for school age children and adolescents. Troubleshooting of these problems must be solved in a complex way, because if each problem is considered separately, it decreases efficiency of pedagogical correction programmes (Lopes, 2005). Children with learning difficulties and cognitive or motor disabilities are rarely receiving sufficient support and assistance from qualified specialists (psychologists, speech therapists, rehabilitologists etc.), which results in reduced learning abilities and social skills of students. In the process of teaching of children with learning disabilities it is necessary to focus on the correction of learning difficulties as well as on the correction of emotional disorders and behaviour (Demidova, 2008). Learning environment and planning of teaching process is especially important in the work with children with learning disorders (Reid, Wearmouth, 2008). Collaboration among a wide range of professionals could result in a production of integrative teaching methodology that would improve behavior of students, learning motivation and social integration, especially of those with learning difficulties.

The quality of student's learning as well as the motivation of learning depends on an interaction between the kinds of social and academic goals of students (Covington, 2000). There is a significant and positive relationship between student's motivation and student's perception of learner-centred teaching (Rossi, 2010). Integrative teaching respects interests of students and prevents overload, encourages cognitive functioning and develops learning motivation of students (Petere, 2004).

The aim of the work was: to realize integrative teaching methodology in schools of Latvia and clear out its effect on self-organization, relations and learning motivation of students.

\section{Materials and methods}

An integrative teaching methodology was developed and used in 17 Latvian schools during one study year. This methodology was worked out and realised by pedagogues, psychologists, speech therapists, psychiatrists, rehabilitologists and psychopysiologists. An integrative teaching methodology was formed out of three sections: section A - social adaptation; section $\mathrm{K}$ - development of cognitive skills and section $\mathrm{P}$ - consolidation and harmonization of personality. Students with learning disabilities, cognitive, speech and motor disorders were included in the study groups but healthy students also participated in the groups. 870 students from general education schools and from special education schools participated in the studies of Integrative teaching methodology. Students were divided into 3 age groups: $3-4 ; 5-7$ and 8-12 grade students. All the students and teachers, under whose supervision the methodology was implemented, were questioned before and after being taught according to the integrative teaching methodology. Questionnaires of 615 students who filled them before and after learning of Integrative teaching methodology were included in the final results.

The questionnaire about self-organization problems of students consists of 17 statements and it was divided into four subscales: 1) self-organization problems, 2) motivation problems; 3) hyperactivity problems and 4) attention deficiency problems. Types of answers were: "never", "sometimes", "often" and "very often". For answer "never" 1 point was given, for answer "sometimes" - 2 points, for answer "often" -3 points and for answer "very often" - 4 points. Higher results (points) indicate greater problems of self-organization. The questionnaire was filled by teachers before and after realizing of integrative teaching methodology.

The questionnaire about relations between students and behaviour of students consists from 22 statements and it was divided into four subscales: 1) problems of aggressive behaviour; 2) problems of social anxiety; 3) problems of communication; 4) problems of depressive symptomatic. Types of answers were: "yes", "no", and "I can’t answer". For answer "yes" 1 point was given, for answer "no" 
Int. Conf. SOCIETY. HEALTH. WELFARE.

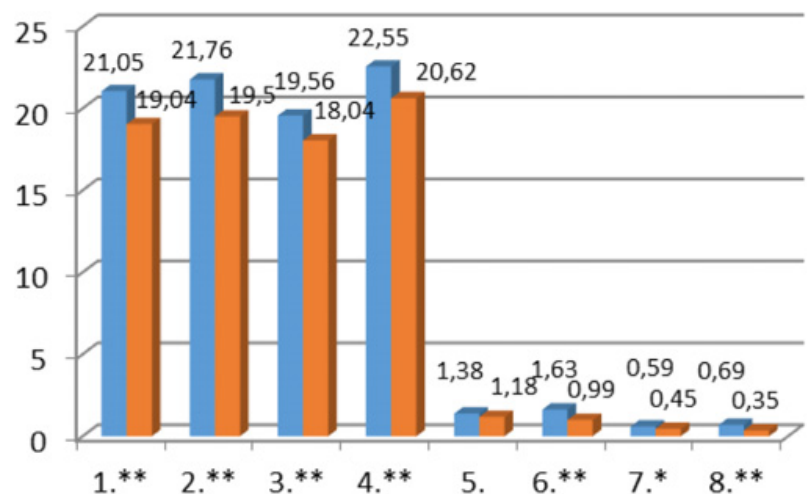

Figure 1. Comparison of self-organization and behaviour problems before $\square$ and after $\square$ realizing of integrative teaching methodology of 3-4 grade students from general education schools. 1. Problems of self-organization. 2. Problems of motivation. 3. Hyperactivity. 4. Deficit of attention. 5. Aggressive behaviour. 6. Social anxiety. 7. Problems of communication. 8. Depressive symptomatology. $* \mathrm{p}<0.05 ; * * \mathrm{p}<0.01$.

or "I can't answer" - 0 points. The questionnaire was filled by teachers before and after realizing of integrative teaching methodology.

The learning motivation questionnaire consists of 13 statements. Three subscales of the questionnaire were distinguished: 1) internal learning motivation, 2) external learning motivation and 3) ammotivation or lack of motivation. Respondents were asked to evaluate every statement with types of answers: "yes", "rather yes", " rather no" or "no". For every answer "yes" 3 points were given, for every answer "rather yes" 2 points were given, for every answer "rather no" 1 point was given and for every answer "no" 0 points were given. Questionnaire was filled by students before and after realizing of integrative teaching methodology.

\section{Results}

The results of investigation showed that after implementation of integrative teaching methodology all assessed self-organization and behaviour problems except aggressive behaviour of 3-4 grade students from general education schools statistically significantly decreased (Fig. 1).

Realising of integrative teaching methodology caused little (not statistically significant) reduction of majority of self-organization and behaviour problems of 3-4 grade students from special education schools (Fig. 2).

After implementation of integrative teaching methodology all assessed self-organization and behaviour problems except hyperactivity of 5-7 grade students from general education schools statistically significantly decreased (Fig. 3).

Implementation of integrative teaching methodology caused little (not statistically significant) reduction of majority of self-organization and behaviour problems except social anxiety of 5-7 grade students from special education schools (Fig. 4). Social anxiety of children statistically significantly reduced.

After implementation of integrative teaching methodology all assessed self-organization and behaviour problems of 8-12 grade students from general education schools statistically significantly decreased (Fig. 5).

Implementation of integrative teaching methodology caused little (not statistically significant) reduction of majority of self-organization and behaviour problems except aggressive behaviour and 
SHS Web of Conferences

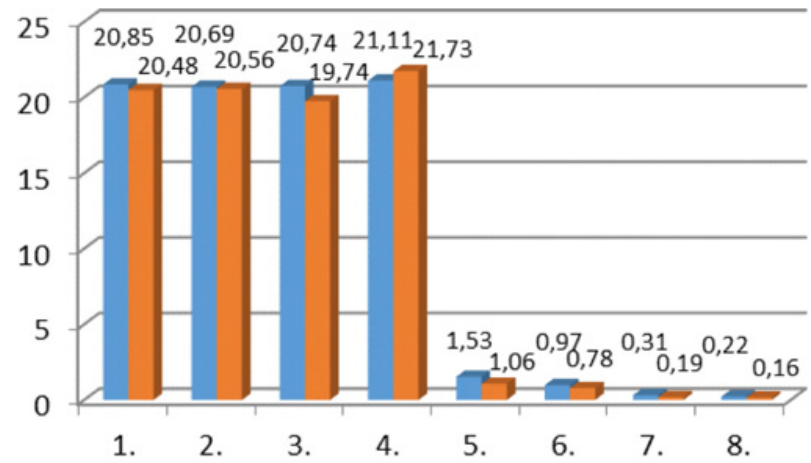

Figure 2. Comparison of self-organization and behaviour problems before $\square$ and after $\square$ realizing of integrative teaching methodology of 3-4 grade students from special education schools. 1. Problems of self-organization. 2. Problems of motivation. 3. Hyperactivity. 4. Deficit of attention. 5. Aggressive behaviour. 6. Social anxiety. 7. Problems of communication. 8. Depressive symptomatology.

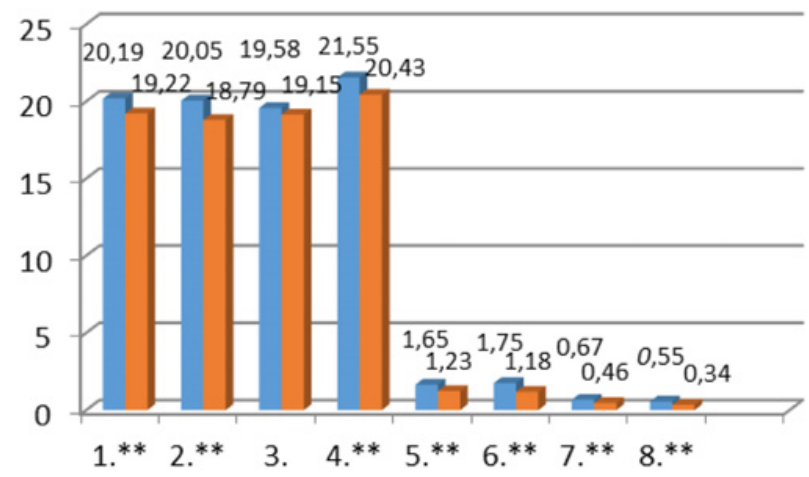

Figure 3. Comparison of self-organization and behaviour problems before $\square$ and after $\square$ implementation of integrative teaching methodology of 5-7 grade students from general education schools. 1. Problems of selforganization. 2. Problems of motivation. 3. Hyperactivity. 4. Deficit of attention. 5. Aggressive behaviour. 6. Social anxiety. 7. Problems of communication. 8. Depressive symptomatology. $* * p<0.01$.

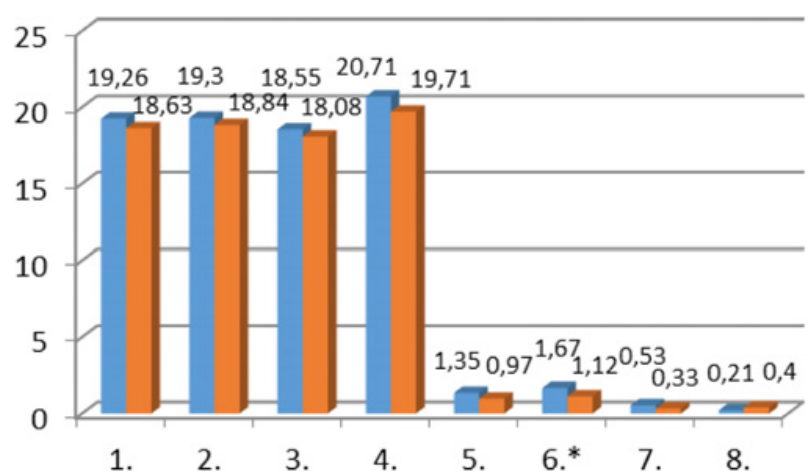

Figure 4. Comparison of self-organization and behaviour problems before $\square$ and after $\square$ realizing of integrative teaching methodology of 5-7 grade students from special education schools. 1. Problems of self-organization. 2. Problems of motivation. 3. Hyperactivity. 4. Deficit of attention. 5. Aggressive behaviour. 6. Social anxiety. 7. Problems of communication. 8. Depressive symptomatology. $* \mathrm{p}<0.05$. 
Int. Conf. SOCIETY. HEALTH. WELFARE.

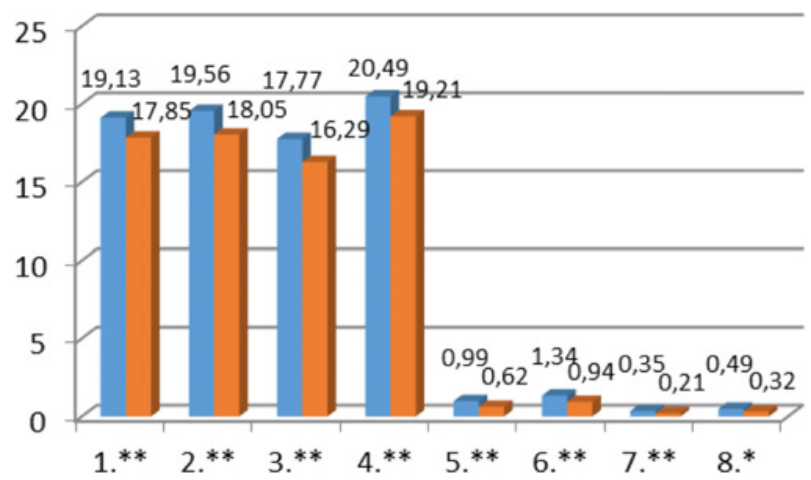

Figure 5. Comparison of self-organization and behaviour problems before $\square$ and after $\square$ realizing of integrative teaching methodology of 8-12 grade students from general education schools. 1. Problems of self-organization. 2. Problems of motivation. 3. Hyperactivity. 4. Deficit of attention. 5. Aggressive behaviour. 6. Social anxiety. 7. Problems of communication. 8. Depressive symptomatology. * $\mathrm{p}<0.05 ; * * \mathrm{p}<0.01$.

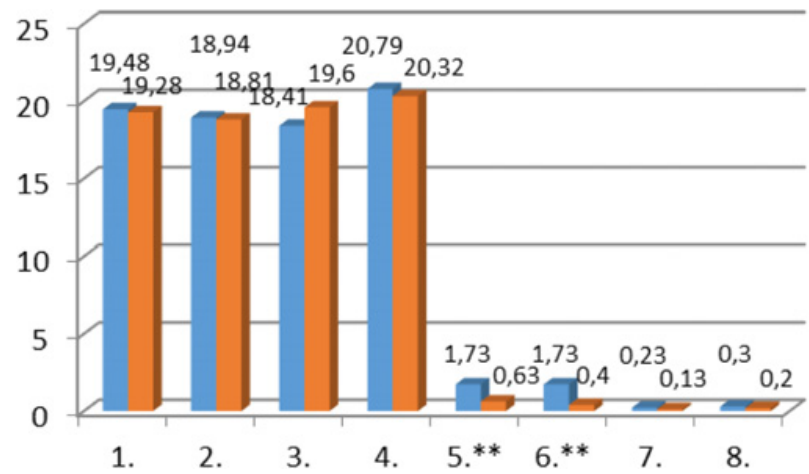

Figure 6. Comparison of self-organization and behaviour problems before $\square$ and after $\square$ realizing of integrative teaching methodology of 8-12 grade students from special education schools. 1. Problems of self-organization. 2. Problems of motivation. 3. Hyperactivity. 4. Deficit of attention. 5. Aggressive behaviour. 6. Social anxiety. 7. Problems of communication. 8. Depressive symptomatology. $* * \mathrm{p}<0.01$.

social anxiety of 8-12 grade students from special education schools (Fig. 6). Aggressive behaviour and social anxiety of children statistically significantly reduced.

The results of student's questionnaire about learning motivation showed that in all age groups of general education schools (Fig. 7) as well as in all age groups of special education schools (Fig. 8), after realizing of integrative teaching methodology, all aspects of student's learning motivation improved: external and internal learning motivation statistically significantly increased but amotivation (or lack of motivation) statistically significantly decreased. These results demonstrate the significant impact of integrative teaching methodology on student's learning motivation.

\section{Discussion}

Science, Technology, Engineering, and Mathematics teachers teach multiple concepts that lend themselves to possible collaboration on a daily basis (Brown et al. 2011). The data of literature give evidence that integrative approach among science, technology, engineering and mathematics (STEM) subjects positively affect student's learning. With respect to the grade levels, the effects of integrative 


\section{SHS Web of Conferences}

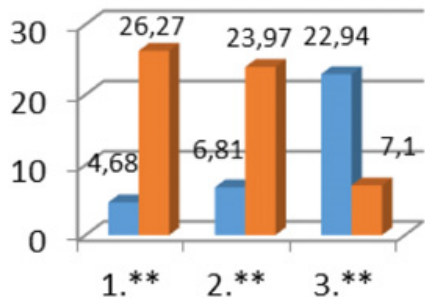

A.

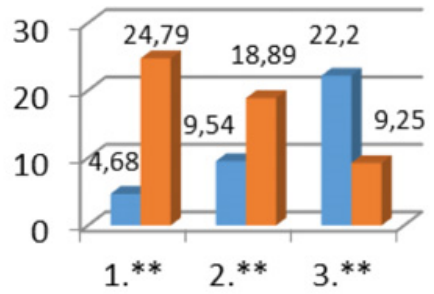

B.

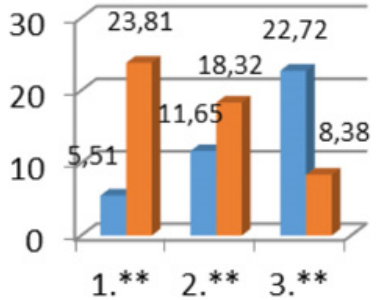

C.

Figure 7. Comparison of learning motivation before $\square$ and after $\square$ realizing of integrative teaching methodology of students from general education schools. 1. External learning motivation. 2. Internal learning motivation. 3. Amotivation (lack of motivation). ** $\mathrm{p}<0,01$. A. 3-4 grade students. B. 5-7 grade students. C. 8-12 grade students.

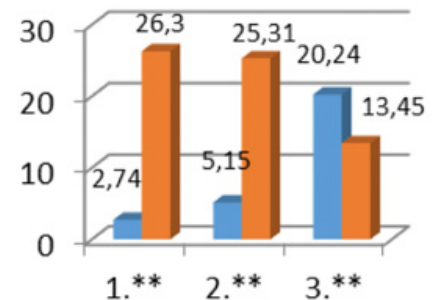

A.

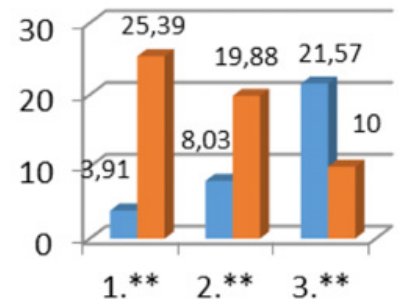

B.

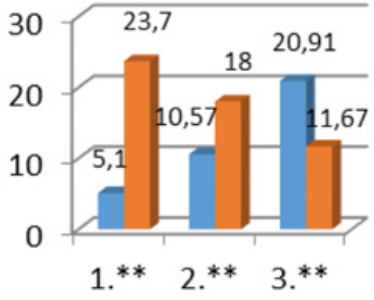

C.

Figure 8. Comparison of learning motivation before $\square$ and after $\square$ realizing of integrative teaching methodology of students from special education schools. 1. External learning motivation. 2. Internal learning motivation. 3. Ammotivation (lack of motivation). ${ }^{* *} \mathrm{p}<0,01$. A. 3-4 grade students. B. 5-7 grade students. C. 8-12 grade students.

approaches showed the largest effect size at the elementary school level and the smallest effect size at the college level (Becker, Kyungsuk, 2011). Results of our investigation show that integrative teaching methodology decrease self-organization and behaviour problems in different age groups of students (34, 5-7 and 8-12 grade students) but in special schools self-organization and behaviour problems of student's have reduced less than in general schools. These results could be explained with the features of special school student groups. Many special school students who acquired integrative teaching methodology have learning and language difficulties, as well as disorders of cognitive and motor functions. In general education schools the quantity of students with different disorders was less than in special schools. Possibly it is one of the main reasons why integrative teaching methodology more influenced self-organization and behaviour of student's in general schools in comparison with special schools. Learning motivation noticeably improved in both groups of schools. This fact suggests that students were interested in integrative teaching methodology in general as well as in special schools. The reviews of teachers and students from different schools confirm this assumption. Teachers told that many students were ready to continue studies of integrative teaching methodology even after the end of study year.

\section{Conclusions}

1. Realizing of integrative teaching methodology in general education schools has significantly reduced problems of self-organization, motivation, hyperactivity, attention deficiency, social 


\section{Int. Conf. SOCIETY. HEALTH. WELFARE.}

anxiety, communication and depressive symptomatic of students in all age groups but in 5-7 and 8-12 grade groups of student's aggressive behaviour as well.

2. Self-organization and behaviour problems in special schools, after implementation of integrative teaching methodology, have less reduced in comparison with general education schools. In 5-7 grade groups of students social anxiety has significantly reduced but in 8-12 grade groups of students social anxiety and aggressive behaviour has significantly reduced.

3. In general education schools as well as in special schools, all age student groups showed a significant increase in parameters of external learning motivation and internal learning motivation but levels of ammotivation statistically significantly decreased after implementation of integrative teaching methodology.

4. Implementation of integrative teaching methodology improved self-organization and learning motivation but decreased behaviour problems of students of general as well as special schools. Improvement of self-organization and behaviour of students in general schools was more pronounced in comparison with special schools.

\section{References}

[1] Anspoka, Z. (1999). Integrēts latviešu valodas mācību saturs un tā metodika sākumskolā [Integrative Learning Content of Latvian Language and its Methodology in the Primary School]. Promocijas darbs. Rīga: Latvijas Universitāte, 147 lpp. (in Latvian).

[2] Becker, K., Kyungsuk, P. (2011). Effects of integrative approaches among science, technology, engineering, and mathematics (STEM) subjects on students' learning: A preliminary metaanalysis. Journal of STEM Education: Innovations \& Research; 12 (5/6), 23-37.

[3] Brown, J., Brown, R., Merill, C. (2011). Science Technology Educators' Enacted Curriculum: Areas of Possible Collaboration for an Integrative STEM Approach in Public Schools. Technology \& Engineering Teacher, 71 (4), 30-34.

[4] Covington, M.V. (2000). Goal theory, motivation, and school achievement: an integrative review. Annual Review of Psychology, 51, 171-200.

[5] Demidova, G. (2008). Mācīšanās traucējumu noteikšana un palīdzības iespējas [Detection of Learning Disorders and Opportunities of Assistance]. Metodiskais materiāls. Rīga: RD IJSD, 46 lpp. (in Latvian).

[6] Lopez, J. (2005). Intervention with Students with Learning, Emotional and Behavioral Disorders: Why Do We Take so Long to Do It? Education and Treatment of children. 28 (4), 311-327.

[7] Miķelsone, I. (2002). Mācību metodes sociālajās zin̄̄bās [Teaching Methods in Social Sciences]. Rīga: Raka, 135 lpp. (in Latvian).

[8] Pedagoǵijas terminu skaidrojošā vārdnīca [Glossary of Pedagogical Terms]. (2000). I. Beļickis, D. Blūma, T. Koķe, D. Markus, A. Šalme, V. Skujiņa (vad.). Rīga: Zvaigzne ABC, 248 lpp. (in Latvian).

[9] Petere A. (2004). Integrētās mācības humānās paradigmas skatījumā [Integrative Teaching from the Point of View of Humanitarian Paradigm]. RPIVA Zinātniskie raksti IV. (134. -140. lpp.). Rìga: RPIVA. (in Latvian).

[10] Reid, G., Wearmouth, J. (2008). Dyslexia and Literacy. USA: John Wiley \& Sons, Ltd., 306 pp.

[11] Rossi, C.M. (2010). A Study of Community College Learner-Centred Teaching Style and Student's Motivation to Learn. ProQuest LLC Ph.D. Dissertation, Saint Louis University, 105 pp.

[12] Šmite, A. (2005). Integrētas mācības [Integrative Teaching]. Skolotājs, 4 (52), 18. - 26. (in Latvian). 